JIKSH: Jurnal Ilmiah Kesehatan Sandi Husada
https://akper-sandikarsa.e-journal.id/JIKSH
Volume 10| Nomor 1| Juni|2021
e-ISSN: 2654-4563 dan p-ISSN: 2354-6093
DOI: https://doi.org/10.35816/jiskh.v10i1.490

Literature Review

\title{
Hubungan Pemberian Asi Eksklusif dengan Kejadian Stunting Pada Balita Umur 24-59 Bulan
}

\author{
Mega Purnamasari ${ }^{1}$, Teti Rahmawati ${ }^{2}$ \\ ${ }^{1}$ Program Sarjana Keperawatan, Sekolah Tinggi Ilmu Kesehatan Jayakarta \\ ${ }^{2}$ Departeman Komunitas, Sekolah Tinggi Ilmu Kesehatan Jayakarta
}

\begin{tabular}{|c|c|}
\hline Artikel info & Abstrak \\
\hline $\begin{array}{l}\text { Artikel history: } \\
\text { Received:28-03-2021 } \\
\text { Reviewed: } 20-04-2021 \\
\text { Revised: 06-05-2021 } \\
\text { Accepted: } 22-05-2021 \\
\text { Published: } 30-06-2021\end{array}$ & $\begin{array}{l}\text { Pendahuluan: Stunting merupakan kondisi balita yang memiliki } \\
\text { panjang atau tinggi badan kurang jika dibandingkan dengan } \\
\text { umur. Stunting dapat disebabkan oleh pemberian. Tujuan } \\
\text { mendeskripsikan hubungan pemberian ASI eksklusif dengan } \\
\text { kejadian stunting pada balita umur } 24-59 \text { bulan. Metode; studi } \\
\text { literatur Hasil; studi menunjukan bahwa pemberian ASI } \\
\text { eksklusif memiliki hubungan yang signifikan dengan kejadian } \\
\text { stunting pada balita umur } 24-59 \text { bulan. Kesimpulan; dimana } \\
\text { balita yang mendapatkan ASI eksklusif akan mengurangi resiko } \\
\text { kejadian stunting. }\end{array}$ \\
\hline
\end{tabular}

Keywords:

Toddlers 24-59 months; Exclusive breastfeeding; Stunting;
Abstract. Introduction: Stunting is a condition of toddlers who have less length or height when compared to age. Stunting can be caused by giving. The aim of describing the relationship between exclusive breastfeeding and the incidence of stunting in infants aged 24-59 months. Method; study literature results; studies show that exclusive breastfeeding has a significant relationship with the incidence of stunting in toddlers aged 2459 months. Conclusion; where toddlers who are exclusively breastfed will reduce the risk of stunting.

\section{Coresponden author:}

Email

\section{: Teti Rahmawati}

: tetirahmawati97@gmail.com

\section{Pendahuluan}

Stunting merupakan masalah kesehatan masyarakat yang berhubungan dengan peningkatan risiko morbiditas, kematian, dan hambatan pertumbuhan motorik dan mental (Rahmadhita, 2020). Angka kejadian stunting mengalami peningkatan dari tahun ketahun. Data secara global menunjukkan bahwa angka kejadian stunting tahun 2018 di perkirakan 21,9\% atau 149 juta anak dibawah umur 5 tahun sedangkan di Asia Tenggara terdapat 14,4 juta anak dibawah umur 5 tahun mengalami stunting (UNICEF/WHO/World Bank Group, 2019). Berdasarkan data Sustainable Development Goals (SDGs) tahun 2018 Indonesia merupakan negara ke tiga di Asia Tenggara dengan stunting umur dibawah 5 tahun sebesar 36,4\% (SDGs, 2018).

Hasil Riset Kesehatan Dasar (Riskesdas) tahun 2013 menunjukkan bahwa angka kejadian stunting secara nasional adalah 37,2\% (Kementerian Kesehatan RI, 2013). Sedangkan pada tahun 2018 angka kejadian stunting secara nasional adalah 30,8\% (Kemenkes RI, 2018a). Meskipun angka kejadian stunting dalam 5 tahun terakhir sudah menurun namun angka tersebut 
JIKSH: Jurnal Ilmiah Kesehatan Sandi Husada

Volume 10 Nomor 1 Juni 2021

masih diatas standar yang ditetapkan oleh WHO yaitu sebesar 20\% (Kemenkes RI, 2018b). Berdasarkan hasil Pemantauan Status Gizi (PSG) tahun 2017 status gizi balita umur 0-59 diwilayah Provinsi DKI Jakarta jumlah balita pendek dan sangat pendek (TB/U) sebanyak 22,7\% balita (Direktorat Gizi Masyarakat, 2018). Jakarta Timur sebagai salah satu wilayah DKI Jakarta menempati posisi kedua dengan jumlah balita pendek dan sangat pendek (TB/U) yaitu sebanyak 25,7\% balita (Badan Perencanaan Pembangunan Daerah, 2018).

Keadaan balita dengan postur tubuh yang pendek dapat disebabkan oleh adanya masalah dengan kelenjar endokrin dan anemia (Agustina, R., Mandala, Z., \& Sahara, 2020), yang dialami akibat kondisi ibu saat hamil mengalami anemia yang menyebabkan bayi kekurangan nutrisi sehingga lahir dengan berat badan rendah atau premature (Rahmawati, 2019). Berat badan lahir, panjang badan lahir, usia kehamilan, dan pola asuh ibu mempengaruhi kejadian stunting (Sumardilah \& Rahmadi, 2019). Selain itu, kondisi fisik pendek dan sangat pendek merupakan salah satu akibat dari kurangnya asupan nutrisi/gizi pada balita yang dialami mulai saat berada dalam kandungan, maupun setelah balita lahir sampai umur dua tahun (Dinkes Aceh, 2019). Salah satu penyebab stunting pada anak adalah pemberian ASI Eksklusif tidak diberikan selama enam bulan karena ASI dibutuhkan selama masa tumbuh kembang bayi agar kebutuhan nutrisinya terpenuhi (SJMJ, S. A., Toban, R., \& Madi, 2020). Balita umur 24-59 bulan termasuk dalam kelompok masyarakat yang paling mudah menderita kelainan gizi (golongan masyarakat kelompok rentan gizi), sedangkan pada saat itu mereka sedang mengalami proses pertumbuhan yang relatif pesat (Azriful et al., 2018). Hal ini sesuai dengan pernyataan Sutomo dan Anggraini (2010), pemenuhan gizi yang seimbang selama masa balita bahkan saat balita berada dalam kandungan, sangat penting untuk mencegah terjadinya permasalahan gizi pada masa balita.

Menurut Rivanica dan Oxyandi (2016) Air Susu Ibu (ASI) sangat berperan dalam pemenuhan nutrisi balita. World Health Organization (WHO) (2005) merekomendasikan ASI eksklusif diberikan pada bayi selama 6 bulan pertama kehidupanya, karena ASI memberikan semua energi dan gizi (nutrisi) yang dibutuhkan bayi. Rekomendasi WHO terhadap pemberian ASI secara eksklusif sejalan dengan Keputusan Menteri Kesehatan Nomor 450/MENKES/SK/VI/2004 tentang pemberian ASI secara eksklusif (Kemenkes RI, 2014). Data Profil Anak Indonesia tahun 2018 menunjukkan bahwa sekitar 94,56\% anak umur di bawah dua tahun (baduta) pernah diberi Air Susu Ibu (ASI). Persentase baduta yang pernah diberi ASI relatif lebih tinggi di perdesaan dibandingkan dengan di perkotaan (Windiarto et al., 2018). Berdasarkan data profil kesehatan Indonesia tahun 2018 secara nasional cakupan bayi mendapatkan ASI eksklusif yaitu sebesar 68,74\%. Angka tersebut sudah melampaui target rencana strategi (Renstra) Kementerian Kesehatan tahun 2018 yaitu 47,0\%. Cakupan bayi mendapatkan ASI eksklusif di provinsi DKI Jakarta sebanyak 45,29\% angka ini belum mencapai target rencana strategi (Renstra) Kementerian Kesehatan tahun 2018 (Kementerian Kesehatan RI, 2019). Berdasarkan data profil kesehatan DKI Jakarta tahun 2017 di wilayah Jakarta Timur presentase balita yang mendapatkan ASI eksklusif sebanyak 61,22\% lebih rendah jika dibandingkan dengan wilayah Jakarta Utara $71,67 \%$ sebagai wilayah tertinggi presentasi pemberian ASI eksklusif (Dinkes Provinsi DKI Jakarta, 2017).

Menurut Tim Nasional Percepatan Penanggulangan Kemiskinan (2017), stunting disebabkan oleh faktor multi dimensi dan tidak hanya disebabkan oleh faktor gizi buruk yang dialami oleh ibu hamil maupun anak balita. Menurut Stewart et al., (2013) dalam Permadi, et al., (2016) penyebab masalah stunting salah satunya adalah akibat dari pemberian Air Susu Ibu (ASI) tidak eksklusif, penundaan Inisiasi Menyusi Dini (IMD), dan penyapihan ASI yang terlalu cepat. Banyaknya faktor yang dapat menyebabkan stunting, membuat penanganan stunting harus dilakukan secara komprehensif. Karena, stunting yang tidak ditangani dapat mengakibatkan penurunan kemampuan kognitif dan prestasi belajar anak (Sutomo \& Anggraini, 2010). Pencegahan kejadian stunting yang dapat dilakukan pada masa balita adalah terpenuhinya kebutuhan nutrisi sehingga balita dapat tumbuh dan berkembang dengan optimal. 
Mega Purnamasari, dkk.Teti Rahmawati ${ }^{2}$ Hubungan Pemberian Asi Eksklusif dengan .......

Salah satu faktor yang dapat memenuhi kebutuhan nutrisi balita dalah pemberian ASI ekslusif yang diberikan pada 6 bulan pertama kehidupan. Banyak studi yang telah dilakukan untuk penyebab kejadian stunting pada balita umur 24-59 bulan. Tujuan studi literatur ini dilakukan menganalisis hubungan pemberian ASI eksklusif dengan kejadian stunting pada balita umur 2459 bulan.

\section{Metode}

Desain penelitian ini adalah penelitian kepustakaan (literature review). Hal ini dilakukan karena peneliti tidak dapat melakukan penelitian secara langsung dilapangan dikarenakan sedang terjadi pandemic virus corona (covid-19). Jenis data yang digunakan adalah data sekunder. Sumber data dalam penelitian literature review ini diperoleh melalui situs pencarian jurnal terpercaya yaitu Google Scholar dalam kurun waktu tahun 2017 sampai tahun 2020. Metode analisis yang digunakan menggunakan analisis isi jurnal dokumen ini menggunakan jurnal-jurnal penelitian online yang diperoleh melalui situs pencarian jurnal terpercaya dengan kriteria inklusi sebagai berikut:

a. Jurnal-jurnal penelitian online megenai pemberian ASI eksklusif dengan kejadian stunting pada balita umur 24-59 bulan (2-5 tahun),

b. Jurnal penelitian online yang digunakan berada dalam rentang waktu 3 tahun terakhir (tahun 2017 sampai tahun 2020),

c. Jurnal-jurnal penelitian online yang berkelas nasional dan internasional

d. Terdapat nomor ISSN (International Standard Serial Number) baik dalam versi cetak maupun elektronik atau $\mathrm{P}$ dan I dalam jurnal penelitian

e. terdapat Digital Object Identifier (DOI) dalam jurnal penelitian

f. Jurnal-jurnal penelitian diperoleh melalui situs pencarian jurnal terpercaya (Google Scholar)

g. Jurnal penelitian full text

Proses pencarian jurnal online melalui situs pencarian jurnal terpercaya:

a Google Scholar. Untuk memperoleh jurnal penelitian online, peneliti menggunakan kata kunci ASI eksklusif dan stunting, dalam kurun waktu kapan saja, ditemukan sebanyak 2.170 jurnal penelitian online. Kemudian peneliti mempersempit pencarian jurnal dengan menggunakan kata kunci ASI Eksklusif dan Stunting dan umur 2-5 tahun, dalam rentang waktu tahun 2019-2020, ditemukan sebanyak 252 jurnal penelitian online. Dari 252 jurnal penelitian online tersebut peneliti membaca melalui abstrak untuk memastikan jurnal tersebut sesuai dengan kriteria inklusi yang peneliti tetapkan. Setelah membaca abstrak peneliti hanya memilih 1 jurnal penelitian online di Indonesia. Jurnal penelitian online yang tidak terpilih adalah jurnal penelitian online yang tidak sesuai dengan kriteria inklusi yang telah ditetapkan dalam penelitian ini

b Google Scholar. Untuk menemukan jurnal penelitian online lainnya peneliti mengubah kata kunci menjadi ASI Eksklusif dan Stunting dan umur 24-59 bulan, dalam waktu pencarian tahun 2017, dan ditemukan 396 jurnal penelitian online. Kemudian dari 396 jurnal penelitian online tersebut peneliti membaca melalui abstrak untuk memastikan jurnal tersebut sesuai dengan kriteria inklusi. Setelah membaca abstrak peneliti hanya memilih 1 jurnal penelitian online di Indonesia. Jurnal penelitian online yang tidak terpilih adalah jurnal penelitian online yang tidak sesuai dengan kriteria inklusi yang telah ditetapkan dalam penelitian ini

c Google Scholar. Pencarian pada tahun 2018 sudah dilakukan, namun tidak ditemukan jurnal penelitian online yang sesuai dengan kriteria inklusi yang telah ditetapkan dalam penelitian ini.

d Google Scholar. Untuk memperoleh jurnal peneitian online yang berasal dari luar Indonesia, peneliti mengganti kata kunci menjadi stunting breast milk with stunting and children, dalam kurun waktu tahun 2020, dan ditemukan sebanyak 1.290 jurnal penelitian online. Kemudian peneliti mempersempit pencarian jurnal dengan menggunakan kata kunci stunting breast milk with stunting and children of age "24 to 59 months", dalam rentang waktu tahun 2020, 
ditemukan sebanyak 44 jurnal penelitian online. Kemudian dari 44 jurnal penelitian online tersebut peneliti membaca melalui abstrak untuk memastikan jurnal tersebut sesuai dengan kriteria inklusi yang peneliti tetapkan. Setelah membaca abstrak peneliti hanya memilih 1 jurnal penelitian online di Indonesia. Jurnal penelitian online yang tidak terpilih adalah jurnal penelitian online yang tidak sesuai dengan kriteria inklusi.

\section{Hasil dan Pembahasan}

Tabel 1 Hasil Literature Riview

\begin{tabular}{|c|c|c|c|c|c|}
\hline No. & $\begin{array}{c}\text { Penulis, dan } \\
\text { Judul } \\
\text { Penelitian } \\
\end{array}$ & $\begin{array}{c}\text { Tujuan } \\
\text { Penelitian }\end{array}$ & $\begin{array}{c}\text { Lokasi, dan } \\
\text { Waktu } \\
\text { Penelitian } \\
\end{array}$ & Metode Penelitian & Hasil Penelitian \\
\hline 1. & $\begin{array}{l}\text { Erna Eka } \\
\text { Wijayanti. } \\
\text { Hubungan } \\
\text { Antara } \\
\text { BBLR, ASI } \\
\text { Eksklusif } \\
\text { dengan } \\
\text { Kejadian } \\
\text { Stunting Pada } \\
\text { Balita Umur } \\
\text { 2-5 Tahun. } \\
\text { Diterbitkan } \\
\text { tahun 2019. }\end{array}$ & $\begin{array}{l}\text { Tujuan } \\
\text { penelitian ini } \\
\text { adalah untuk } \\
\text { mengetahui } \\
\text { hubungan antara } \\
\text { BBLR, ASI } \\
\text { eksklusif } \\
\text { dengan kejadian } \\
\text { stunting pada } \\
\text { balita umur 2-5 } \\
\text { tahun di desa } \\
\text { Jadi Kecamatan } \\
\text { Semanding } \\
\text { Kabupaten } \\
\text { Tuban. }\end{array}$ & $\begin{array}{l}\text { Penelitian } \\
\text { ini dilakukan } \\
\text { di Desa Jadi } \\
\text { Kecamatan } \\
\text { Semanding } \\
\text { Kabupaten } \\
\text { Tuban, Jawa } \\
\text { Timur, } \\
\text { Indonesia. } \\
\text { Penelitian } \\
\text { ini dilakukan } \\
\text { pada tahun } \\
\text { 2018. }\end{array}$ & 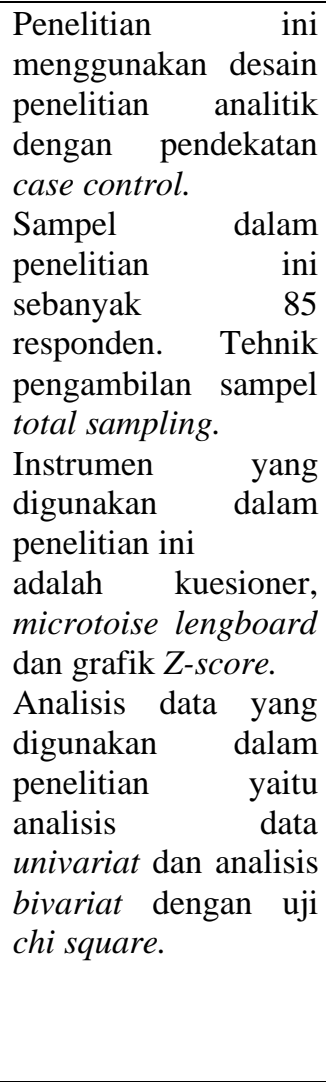 & $\begin{array}{l}\text { Penelitian } \\
\text { menunjukkan bahwa } \\
\text { dari } 47 \text { balita yang } \\
\text { tidak mendapatkan } \\
\text { ASI eksklusif hampir } \\
\text { seluruhnya mengalami } \\
\text { stunting sebanyak } 44 \\
\text { responden (94\%). } \\
\text { Sedangkan balita yang } \\
\text { diberikan } \\
\text { eksklusif } \\
\text { seluruhnya nampir } \\
\text { sebanyak normal } \\
\text { responden (79\%). } \\
\text { Berdasarkan hasil uji } \\
\text { chi square diperoleh } \\
\text { nilai p= (0,000) yang } \\
\text { lebih kecil dari nilai } \alpha \\
\text { (0,05) yang berarti } \\
\text { ada hubungan antara } \\
\text { ASI eksklusif dengan } \\
\text { kejadian Stunting } \\
\text { pada balita umur } 2-5 \\
\text { tahun di desa Jadi } \\
\text { Kecamatan } \\
\text { Semanding-Tuban. }\end{array}$ \\
\hline 2. & $\begin{array}{l}\text { Dewi } \\
\text { Purnama } \\
\text { Windasari, } \\
\text { Ilham Syam, } \\
\text { dan Lilis } \\
\text { Sarifa Kamal. } \\
\text { Faktor } \\
\text { Hubungan } \\
\text { Dengan } \\
\text { Kejadian } \\
\text { Stunting Di } \\
\text { Puskesmas } \\
\text { Tamalate } \\
\text { Kota } \\
\text { Makassar } \\
\text { (Factors } \\
\text { Related To }\end{array}$ & $\begin{array}{l}\text { Penelitian ini } \\
\text { bertujuan untuk } \\
\text { mengetahui } \\
\text { hubungan } \\
\text { penyakit infeksi, } \\
\text { inisiasi } \\
\text { menyusui dini, } \\
\text { riwayat asi } \\
\text { eksklusif, BBLR } \\
\text { dan pernikahan } \\
\text { dini dengan } \\
\text { kejadian } \\
\text { stunting. }\end{array}$ & $\begin{array}{l}\text { Penelitian } \\
\text { ini dilakukan } \\
\text { di wilayah } \\
\text { kerja } \\
\text { Puskesmas } \\
\text { Tamalate } \\
\text { Kota } \\
\text { Makassar. } \\
\text { Penelitian } \\
\text { ini dilakukan } \\
\text { pada tahun } \\
\text { 2019. }\end{array}$ & $\begin{array}{lr}\text { Metode } & \text { yang } \\
\text { digunakan } & \text { pada } \\
\text { penelitian ini adalah } \\
\text { observasional analitik } \\
\text { dengan pendekatan } \\
\text { cross-sectional study. } \\
\text { Sampel } \\
\text { penelitian } \\
\text { sebanyak } & \text { dalam } \\
\text { Teknik pengambilan } \\
\text { sampel parposive } \\
\text { sampling }\end{array}$ & 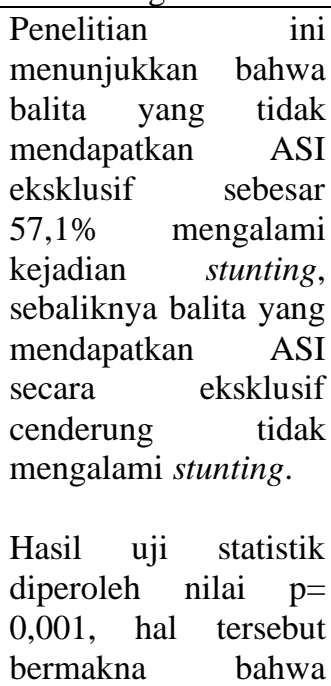 \\
\hline
\end{tabular}


Mega Purnamasari, dkk.Teti Rahmawati ${ }^{2}$ Hubungan Pemberian Asi Eksklusif dengan .......

\begin{tabular}{|c|c|c|c|c|c|}
\hline & $\begin{array}{l}\text { The Incidence } \\
\text { Of Stunting } \\
\text { At The } \\
\text { Tamalate } \\
\text { Health Center } \\
\text { In Makassar } \\
\text { City). } \\
\text { Diterbitkan } \\
\text { tahun 2020. }\end{array}$ & & & $\begin{array}{lr}\text { Analisis data yang } \\
\text { digunakan } \\
\text { penelitian dalam } \\
\text { analisis yaitu } \\
\text { menggunakan bivariat } \\
\text { Chisquare uji } \\
\text { analisis uji } r \text { dan } \\
\text { Exact test pada } \\
\text { tingkat kemaknaan } \\
95 \% \text {. }\end{array}$ & $\begin{array}{l}\text { pemberian ASI } \\
\text { eksklusif mempunyai } \\
\text { hubungan signifikan } \\
(\mathrm{p}<0,05) \text { dengan } \\
\text { kejadian stunting pada } \\
\text { balita di wilayah kerja } \\
\text { Puskesmas Tamalate. }\end{array}$ \\
\hline 3. & $\begin{array}{l}\text { Molla } \\
\text { Kahssay, } \\
\text { Etsay Woldu, } \\
\text { Abel Gebre } \\
\text { dan Surender } \\
\text { Reddy. } \\
\text { Determinants } \\
\text { of stunting } \\
\text { among } \\
\text { children aged } \\
6 \quad \text { to } 59 \\
\text { months in } \\
\text { pastoral } \\
\text { community, } \\
\text { Afar Region, } \\
\text { North East } \\
\text { Ethiopia: } \\
\text { unmatched } \\
\text { case control } \\
\text { study. } \\
\text { Diterbitkan } \\
\text { tahun 2020. }\end{array}$ & $\begin{array}{l}\text { Tujuan } \\
\text { penelitian ini } \\
\text { adalah untuk } \\
\text { mengidentifikasi } \\
\text { faktor penentu } \\
\text { stunting pada } \\
\text { anak umur } 6 \\
\text { sampai } 59 \text { bulan } \\
\text { di Pedesaan } \\
\text { Kabupaten } \\
\text { Dubti, Wilayah } \\
\text { Afar, Ethiopia } \\
\text { Timur Laut }\end{array}$ & $\begin{array}{l}\text { Penelitian } \\
\text { ini dilakukan } \\
\text { di Pedesaan } \\
\text { Kabupaten } \\
\text { Dubti, } \\
\text { Wilayah } \\
\text { Afar. } \\
\text { pada tahun } \\
2017 .\end{array}$ & 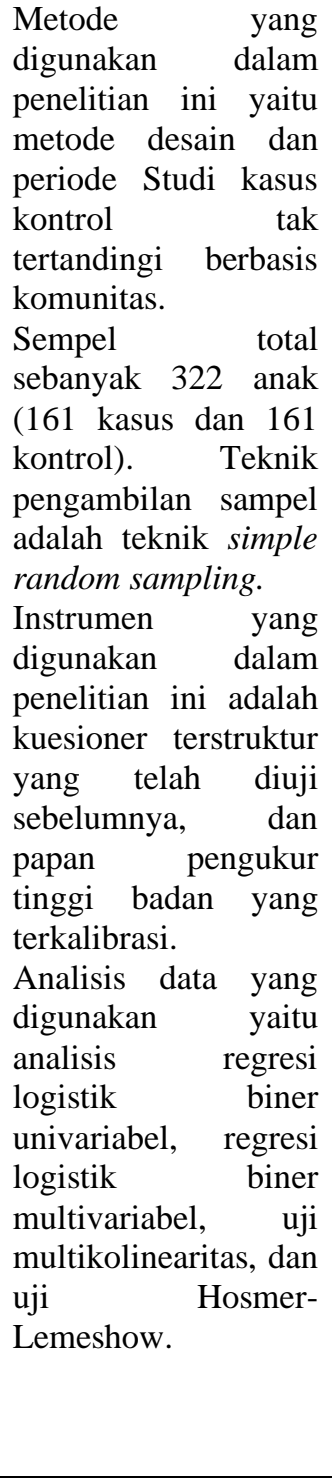 & 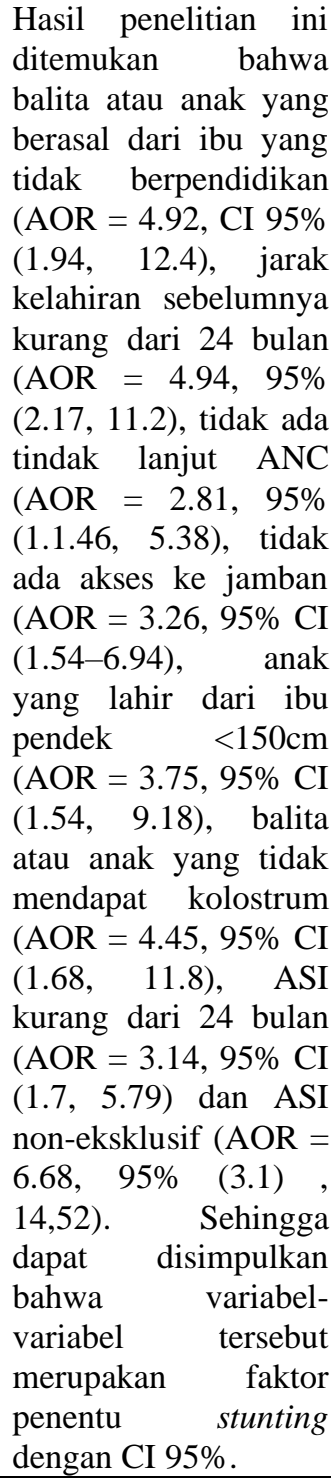 \\
\hline
\end{tabular}

Beberapa penelitian telah dilakukan untuk mengetahui penyebab kejadian stunting pada balita khususnya balita umur 24-59 bulan. Beberapa penelitian tersebut mengatakan bahwa kejadian stunting pada balita dapat disebabkan oleh ASI eksklusif yang diterima oleh balita. Penelitian tersebut dilakukan didalam maupun di luar Indonesia untuk mengetahuai penyebab dari kejadian stunting. Berdasarkan penelitian yang dilakukan oleh Wijayanti (2019), Windasari 
JIKSH: Jurnal Ilmiah Kesehatan Sandi Husada

Volume 10 Nomor 1 Juni 2021

et al., (2020) dan Kahssay et al., (2020) bahwa mayoritas umur pada setiap responden yang mengalami stunting yaitu umur antara 24 sampai 59 bulan atau dibawah umur 5 tahun atau biasa disebut dengan balita. Menurut Kementerian Kesehatan RI (2015) balita adalah anak yang telah menginjak umur diatas satu tahun atau lebih popular dengan pengertian anak dibawah umur lima tahun. Balita umur 24-59 bulan termasuk dalam kelompok masyarakat yang paling mudah menderita kelainan gizi (golongan masyarakat kelompok rentan gizi), sedangkan pada saat itu mereka sedang mengalami proses pertumbuhan yang relatif pesat (Azriful et al., 2018). Hal ini sesuai dengan pernyataan Sutomo dan Anggraini (2010), pemenuhan gizi yang seimbang selama masa balita bahkan saat balita berada dalam kandungan, sangat penting untuk mencegah terjadinya permasalahan gizi pada masa balita.

Pemberian ASI eksklusif merupakan salah satu upaya untuk memenuhi kebutuhan gizi pada masa balita. Hal ini sejalan dengan Rivanica dan Oxyandi (2016) yang mengatakan bahwa Air Susu Ibu (ASI) sangat berperan dalam pemenuhan nutrisi balita. WHO pada tahun 2005 merekomendasikan pemberian ASI eksklusif diberikan pada bayi selama 6 bulan pertama kehidupanya, karena ASI memberikan semua energi dan gizi (nutrisi) yang dibutuhkan bayi selama 6 bulan pertama kehidupannya, pemberian ASI eksklusif dapat mengurangi tingkat kematian bayi yang disebabkan oleh berbagai penyakit (Yuliarti, 2010). Rekomendasi WHO terhadap pemberian ASI secara eksklusif sejalan dengan Keputusan Menteri Kesehatan Nomor 450/MENKES/SK/VI/2004 tentang pemberian ASI secara eksklusif (Kemenkes RI, 2014).

Kemenkes RI (2018c) mengatakan bahwa stunting (kerdil) adalah kondisi dimana balita memiliki panjang atau tinggi badan yang kurang jika dibandingkan dengan umur. Kondisi ini diukur dengan panjang atau tinggi badan yang $>-2$ SD standar pertumbuhan anak dari WHO. Menurut Tim Nasional Percepatan Penanggulangan Kemiskinan (2017) stunting dapat disebabkan oleh praktek pengasuhan yang kurang baik dimana $60 \%$ dari anak umur 0-6 bulan tidak mendapatkan Air Susu Ibu (ASI) secara ekslusif. Hal ini sejalan dengan Stewart et al., (2013) dalam Permadi, et al., (2016) bahwa penyebab masalah stunting salah satunya adalah akibat dari pemberian Air Susu Ibu (ASI) tidak eksklusif, penundaan Inisiasi Menyusi Dini (IMD), dan penyapihan ASI yang terlalu cepat.

Penelitian yang dilakukan oleh Wijayanti (2019) menyatakan bahwa hampir seluruh responden yang tidak mendapatkan ASI eksklusif dalam kondisi sunting (94\%). Ini dapat terjadi karena pengetahuan masyarakat yang kurang (Wijayanti, 2019). Hal ini sejalan dengan dengan penelitian Risadi et al., (2019) yang mengungkapkan bahwa semakin baik pengetahuan manajemen laktasi ibu, maka semakin baik pula perilaku ibu dalam pemberian ASI eksklusif dan sebaliknya. Peneliti bependapat bahwa, jika perilaku ibu baik dalam pemberian ASI eksklusif maka kebutuhan nutrisi balita dapat terpenuhi. Karena ASI eksklusif mengandung zat gizi yang sesuai dengan kebutuhan bayi (Widaryanti 2019). Widaryanti 2019). Penelitian yang dilakukan oleh Wijayanti (2019) sejalan dengan penelitian yang dilakukan di Desa Watugajah Kabupaten Gunung Kidul oleh Handayani, Kapota, dan Oktavianto (2019) yang menyatakan bahwa semakin baik pemberian ASI eksklusif yang dilakukan oleh ibu untuk anaknya, maka semakin baik pula status gizi anak. Dan sebaliknya semakin kurang pemberian ASI eksklusif yang dilakukan oleh ibu untuk anaknya semakin buruk pula status gizi anak (stunting). Wijayanti (2019) dalam penelitiannya menemukan selain pengetahuan masyarakat yang kurang, ternyata terdapat hal lainnya yang menyebabkan orang tua tidak memberikan ASI secara eksklusif yaitu masyarakat masih dipengaruhi oleh budaya yang kental. Menurut pendapat peneliti, budaya yang dimaksud adalah bayi diberikan makanan pada umur kurang dari 6 bulan (MP-ASI dini). Penelitian yang dilakukan oleh Fitri dan Ernita (2019) mengatakan bahwa pemberian MP-ASI yang terlalu dini ini akan berdampak terhadap kejadian infeksi yang tinggi seperti diare, infeksi saluran nafas, alergi hingga gangguan pertumbuhan karena system pencernaan bayi masih belum berfungsi dengan sempurna. Windasari et al., (2020) dalam penelitiannya mengatakan bahwa sebanyak $57,1 \%$ balita yang tidak mendapatkan ASI eksklusif mengalami kondisi stunting. Artinya separuh dari sampel balita stunting dalam penelitiannya dipengaruhi oleh pemberian ASI eksklusif. Windasari et al., (2020) juga mengatakan bahwa 
balita yang mendapatkan ASI eksklusif cenderung tidak mengalami stunting. Penelitian yang dilakukan oleh Latifah, Purwanti, dan Sukamto (2020) yang dilakukan di Posyandu Bangunsari Desa Wagir Kidul wilayah kerja Puskesmas Pulung bahwa kejadian stunting dapat dipengaruhi oleh pemberian ASI eksklusif. Sejalan dengan penelitian SJMJ, S. A., Toban, R., dan Madi, M. (2020) dengan menggunakan uji chi-square diperoleh $\mathrm{p}=0,000(0,000<0,05)$, hal ini menunjukkan ada hubungan pemberian ASI Eksklusif dengan kejadian stunting pada anak dengan uji odds ratio nilai $\mathrm{R}=61$ yang artinya anak yang tidak mendapat ASI Eksklusif 61 kali lebih mungkin mengalami stunting dibandingkan dengan anak yang mendapat ASI Eksklusif.

Menurut penelitian Kahssay et al., (2020) balita yang tidak mendapatkan ASI eksklusif 6,6 kali lebih mungkin terjadi stunting. Hal ini dapat terjadi karena ASI yang diberikan secara eksklusif mengandung kolostrum (Kahssay et al., 2020). Kolostrum mengandung zat kekebalan terutama Ig A untuk melindungi bayi dari penyakit infeksi saluran pencernaan terutama diare Linda (2019). Menurut pendapat peneliti, kolostrum yang terdapat dalam ASI dapat melindungi bayi dari infeksi saluran pencernaan. Jika infeksi pencernaan terjadi maka akan menyebabkan penurunan kebutuhan nutrisi pada balita, kebutuhan nutrisi yang tidak terpenuhi akan menimbulkan permasalah gizi pada balita tersebut. Wulandari et al., (2019) dalam penelitiannya mengatakan bahwa bahwa balita dengan riwayat infeksi pencernaan (diare) dengan kejadian stunting pada balita di Kabupaten Bengkulu Utara. Penelitian yang dilakukan oleh Kahssay et al., (2020) sejalan dengan penelitian yang dilakukan oleh Fikadu et al., (2014) di Distrik Meskan Zona Gurage, Ethiopia Selatan, bahwa anak yang tidak mendapatkan ASI eksklusif sampai umur 6 bulan memiliki risiko 3,27 kali lebih tinggi untuk mengalami stunting dibandingkan anak yang tidak mendapatkan ASI eksklusif samapi 6 bulan.

Berdasarkan penelitian Wijayanti (2019) di Kabupaten Tuban terdapat balita yang diberikan ASI secara eksklusif dengan kondisi stunting (21\%). Hasil penelitian Windasari et al., (2020) di Kota Makassar juga terdapat balita kondisi stunting dengan pemberian ASI secara eksklusif $(28,1 \%)$. Kedua penelitian tersebut memiliki kesamaan yakni sama-sama terdapat balita dengan status ASI eksklusif namun mengalami kondisi stunting. Windasari et al., (2020) dalam penelitiannya menjelaskan bahwa balita yang diberikan ASI secara eksklusif namun bila frekuensi pemberiannya kurang, maka balita tersebut juga akan mengalami kekurangan nutrisi. Peneliti berpendapat bahwa tidak menutup kemungkinan balita yang stunting dengan status ASI eksklusif yang terdapat dalam penelitian Wijayanti (2019) pun memiliki frekuensi pemberian ASI eksklusif, sehingga masih terdapat balita stunting dengan status ASI eksklusif.

Monika (2014) dalam teoinya mengatakan ASI mengandung karbohidat. Karbohidrat utama dalam ASI adalah laktosa yang merupakan komponen utama ASI. Laktosa memenuhi 45$50 \%$ kebutuhan energi bayi. Jenis karbohidrat lain dalam ASI adalah oligosakarida yang memiliki fungsi penting melindungi bayi dari infeksi. Menurut Monika (2014) Dalam ASI juga mengandung Lemak sebanyak 3,5 gram lemak per $100 \mathrm{ml}$. Lemak sangat dibutuhkan sebagai sumber energi dan sebanyak 50\% kebutuhan energi bayi diperoleh dari lemak ASI. Lemak ASI mengandung DHA dan ARA, kedua asam lemak ini sangat penting untuk perkembangan syaraf dan vuisual bayi. ASI juga mengandung enzim lipase yang berperan dalam mencerna lemak dan mengubahnya menjadi energi yang dibutuhkan bayi. Dalam ASI juga terkandung enzim amilase yang berperan dalam mencerna karbohidrat. Dengan demikian jika dilihat dari kandungan yang terdapat dalam ASI akan membantu mengurangi angka kejadian kurang gizi dan pertumbuhan yang terhenti yang umumnya terjadi pada balita.

Penelitian yang dilakukan Sumilat, Malonda, dan Punuh (2019) mengatakan bahwa terdapat hubungan antara pemberian ASI Eksklusif dengan status gizi berdasarkan indeks $(\mathrm{BB} / \mathrm{U})$ dengan nilai $\mathrm{p}=0,024$. Status gizi berdasarkan indeks $(\mathrm{TB} / \mathrm{U})$ dengan nilai $\mathrm{p}=0,031$. Status gizi berdasarkan indeks $(\mathrm{BB} / \mathrm{TB})$ dengan nilai $\mathrm{p}=0,003$. Hasil penelitan Wiwin, Dina, dan Desi (2019) mengenai pemberian ASI ekslusif dengan tumbuh kembang bayi umur 6 bulan didapatkan hasil yaitu terdapat hubungan yang signifikan antara pemberian ASI eksklusif dengan tumbuh kembang bayi umur 6 bulan.

Selain itu menurut Monika (2014) ASI juga mengandung Antiparasit, Antivirus, AntiAlergi, Antibodi yang berfungsi melindungi bayi dari berbagai infeksi, seperti $\mathrm{K}$ - 
JIKSH: Jurnal Ilmiah Kesehatan Sandi Husada

Volume 10 Nomor 1 Juni 2021

imunoglobulin, sIgA (secretory immunoglobulin A) sel darah putih-K, dan K-oligosakarida. Hasil penelitian Rahman dan Nur (2015) menunjukkan bahwa terdapat hubungan yang bermakna antara pemberian ASI Eksklusif dengan kejadian penyakit ISPA. Hal ini menunjukkan Prevalensi kejadian ISPA lebih besar pada anak yang diberi ASI tidak eksklusif dibandingkan pada anak yang diberi ASI secara eksklusif. Stunting dapat menyebabkan penurunan kecerdasan, terhambat pertumbuhan dan perkembangan, penurunan daya tahan tubuh, dan produktivitas yang rendah (Adilla Kamilia, 2019). Stunting dalam jangka panjang akibat buruk yang dapat menurunnya kemampuan kognitif dan prestasi belajar (Yosephin et al., 2019). Pendapat yang di ungkapkan oleh Yosephin et al., (2019) didukung oleh penelitian yang dilakukan Dwi, Yadika, Berawi, dan Nasution (2019) yang mengataka bahwa terdapat hubungan yang signifikan antara stunting dengan IQ sebagai salah satu tanda perkembangan otak, dimana skor IQ pada anak stunting lebih rendah dibandingkan dengan anak non stunting, hal ini dapat terjadi karena stunting di awal kehidupan seorang anak dapat menyebabkan kerusakan permanen pada perkembangan kognitif yang diikuti dengan perkembangan motorik, dan intelektual yang kurang optimal sehingga cenderung dapat menimbulkan konsekuensi terhadap pendidikan, pendapatan, dan produktivitas pada masa dewasa sehingga berpotensi menurunkan pertumbuhan ekonomi.

\section{Simpulan Dan Saran}

Terdapat hubungan yang signifikan antara pemberian ASI eksklusif terhadap kejadian stunting pada balita umur 24-59 bulan. Diharapkan hasil penelitian ini dapat menjadi data dasar untuk melakukan penelitian selanjutnya seperti mengenai dukungan keluarga terhadap pemberian ASI eksklusif dengan mengguakan desain, metode, dan sampel yang berbeda agar didapatkan hasil penelitian yang lebih baik lagi.

\section{Daftar Rujukan}

Adilla Kamilia. (2019). Berat Badan Lahir Rendah dengan Kejadian Stunting pada Anak. Jurnal Ilmiah Kesehatan Sandi Husada, 10(2), 311-315. https://akper-sandikarsa.e-journal.id/JIKSH/article/view/175

Agustina, R., Mandala, Z., \& Sahara, R. (2020). Hubungan Kadar Serum Feritin Dengan Kejadian Stunting Pada Anak Talasemia $\beta$ Mayor. Jurnal Ilmiah Kesehatan Sandi Husada, 11(1), 265-270. https://akper-sandikarsa.e-journal.id/JIKSH/article/view/258

Azriful, Bujawati, E., Habibi, Aeni, S., \& Yusdarif. (2018). Determinan Kejadian Stunting Pada Balita Usia 24-59 Bulan Di Kelurahan Rangas Kecamatan Banggae Kabupaten Majene. 10(2), 192-203.

Badan Perencanaan Pembangunan Daerah. (2018). Prevalensi Gizi Buruk di Jakarta Tinggi, Bappeda Adakan Forum Lintas Bidang Tema Stunting. Badan Perencanaan Pembangunan Daerah Provinsi DKI Jakarta.

Dinkes Aceh. (2019). Cegah Stunting Itu Penting. Dinas Kesehatan Aceh.

Dinkes Provinsi DKI Jakarta. (2017). Profil kesehatan Provinsi DKI Jakarta Tahun 2017.

Direktorat Gizi Masyarakat. (2018). Hasil Pemantauan Status Gizi ( PSG ) Tahun 2017.

Dwi, A., Yadika, N., Berawi, K. N., \& Nasution, S. H. (2019). Pengaruh Stunting terhadap Perkembangan Kognitif dan Prestasi Belajar. 273-282.

Fikadu, T., Assegid, S., \& Dube, L. (2014). Factors Associated With Stunting Among Children Of Age 24 To 59 Months In Meskan District, Gurage Zone, South Ethiopia : A CaseControl Study. 1-7. https://doi.org/https://doi.org/10.1186/1471-2458-14-800

Fitri, L., \& Ernita. (2019). Hubungan Pemberian ASI Eksklusif dan MP ASI Dini Dengan Kejadian Stunting Pada Balita. Ilmu Kebidanan, 8(1).

Handayani, S., Kapota, W. N., \& Oktavianto, E. (2019). Hubungan Status ASI Eksklusif Dengan Kejadian Stunting Pada Batita Usia 24-36 Bulan Di Desa. Jurnal Ilmiah Kesehatan, 14(4), 287-300.

Kahssay, M., Woldu, E., Gebre, A., \& Reddy, S. (2020). Determinants of stunting among 
Mega Purnamasari, dkk.Teti Rahmawati ${ }^{2}$ Hubungan Pemberian Asi Eksklusif dengan .......

children aged 6 to 59 months in pastoral community, Afar region, North East Ethiopia: unmatched case control study. BMC Nutrition, 6(1), 1-8. https://doi.org/10.1186/s40795020-00332-z

Kemenkes RI. (2014). Infodatin ASI.

Kemenkes RI. (2018a). Hasil Utama Riskesdas 2018 (2018th ed.). Kementerian Kesehatan.

Kemenkes RI. (2018b). Penurunan Stunting Jadi Fokus Pemerintah. Kementerian Kesehatan RI.

Kemenkes RI. (2018c). Situasi Balita Pendek (Stunting) di Indonesia (E. S. Sakti (ed.); 1st ed.). Pusat Data dan Informasi.

Kementerian Kesehatan RI. (2013). Riset Kesehatan Dasar.

Kementerian Kesehatan RI. (2015). Infodatin-Anak-Balita. In kemenkes RI, Pusat data dan informasi (Issue situasi kesehatan anak balita di Indonesia, pp. 1-8). Kementerian Kesehatan.

Kementerian Kesehatan RI. (2019). Profil Kesehatan Indonesia 2018.

Latifah, A. M., Purwanti, L. E., \& Sukamto, F. I. (2020). Hubungan Pemberian Asi Eksklusif Dengan Kejadian Stunting Pada Balita 1-5 Tahun. Health Sciences Journal, 4(1), 142. https://doi.org/10.24269/hsj.v4i1.409

Linda, E. (2019). ASI Eksklusif. Yayasan Jamiul Fawaid.

Monika, F. . (2014). Buku Pintar ASI dan Menyusui. Noura Books.

Permadi, M. R., Hanim, D., Kusnandar, \& Indarto, D. (2016). Risiko Inisiasi Menyusu Dini Dan Praktek Asi Eksklusif Terhadap Kejadian Stunting Pada Anak 6-24 Bulan (Early Breastfeeding Initiation And Exclusive Breastfeeding As Risk Factors Of Stunting Children 6-24 Months-Old). 36(1). https://doi.org/10.22435/pgm.v39i1.5965.9-14

Rahmadhita, K. (2020). Permasalahan Stunting dan Pencegahannya. Jurnal Ilmiah Kesehatan Sandi Husada, 11(1), 225-229. https://akper-sandikarsa.e-journal.id/JIKSH/article/view/253

Rahman, A., \& Nur, A. F. (2015). Hubungan Pemberian ASI Eksklusif Dengan Kejadian Penyakit Infeksi Saluran Pernafasan Akut Pada Anak Balita Di Wilayah Kerja Puskesmas Managaisaki. 33.

Rahmawati, T. (2019). Dukungan Informasi Suami Dengan Kejadian Anemia Pada Ibu Hamil. Persada Husada Indonesia, 6(22), 50-59.

Risadi, C. A., Mashabi, N. A., \& Prastiti Laras Nugraheni. (2019). Pengaruh Pengetahuan Ibu Mengenai Menejemen Laktasi Terhadap Perilaku Pemberian ASI Eksklusif. https://doi.org/doi.org/10.21009/JKKP.061.04

Rivanica, R., \& Oxyandi, M. (2016). Buku Ajar dan Deteksi Dini Tumbuh Kembang dan Pemeriksaan Bayi Baru Lahir. Salemba Medika.

SDGs. (2018). World Health Statistics 2018: Monitoring Health For The Sustainable Development Goals (SDGs). In World Health Organization 2018 (Vol. 10, Issue 2).

SJMJ, S. A., Toban, R., \& Madi, M. (2020). Hubungan Pemberian ASI Eksklusif Dengan Kejadian Stunting Pada Balita. Jurnal Ilmiah Kesehatan Sandi Husada, 11(1), 448-455. https://akper-sandikarsa.e-journal.id/JIKSH/article/view/314

Sumardilah, D. S., \& Rahmadi, A. (2019). Risiko Stunting Anak Baduta (7-24 bulan). Jurnal Kesehatan, 10(1), 93. https://doi.org/10.26630/jk.v10i1.1245

Sumilat, M. F., Malonda, N. S. H., \& Punuh, M. I. (2019). Hubungan Antara Status Imunisasi Dan Pemberian ASI Eksklusif Dengan Status Gizi Balita Usia 24-59 Bulan Di Desa Tateli Tiga Kecamatan Mandolang Kabupaten Minahasa. Kesehatan Masyarakat, 8(6), 326-334.

Sutomo, B., \& Anggraini, D. Y. (2010). Menu Sehat Alami untuk Balita Battita \&Balita (Pertama). Demedia.

Tim Nasional Percepatan Penanggulangan Kemiskinan. (2017). 1000 Kabupaten/Kota Prioritas untuk Intervensi Anak Kerdil (Stunting) Ringkasan.

UNICEF/WHO/World Bank Group. (2019). Levels and trends in child malnutirtion: key findings of the 2019 Edition of the Joint Child Malnutrition Estimates. 1-15.

Widaryanti, R. (2019). Pemberian Makanan Bayi \& Anak. Deepublish.

Wijayanti, E. E. (2019). Hubungan Antara BBLR, ASI Esklusif dengan Kejadian Stunting Pada 
Balita Usia 2-5 Tahun. 7(1), 36-41. https://doi.org/https://doi.org/10.36858/jkds.v7i1.138

Windasari, D. P., Syam, I., \& Kamal, L. S. (2020). Faktor Hubungan Dengan Kejadian Stunting Di Puskesmas Tamalate Kota Makassar (Factors Related To The Incidence Of Stunting At The Tamalate Health Center In Makassar City ). 2020(5), 27-34. https://doi.org/http://dx.doi.org/10.30867/action.v5i1.193

Windiarto, T., Yusuf, A. H., Nugroho, S., Latifah, S., \& Solih, R. (2018). Pofil Anak Indonesia 2018. In Kementerian Pemberdayaan Perempuan dan Perlindungan Anak (KPPA) (Vol. 5, Issue 1).

Wiwin, F., Dina, A. R., \& Desi, K. (2019). Pemberian ASI Ekslusif dengan Tumbuh Kembang Bayi Usia 6 Bulan di Wilayah Kerja Puskesmas Wates Pringsewu Lampung. 1(February), 109-114.

Wulandari, W. W., Rahayu, F., \& Darmawansyah. (2019). Hubungan Sanitasi Lingkungan Dan Riwayat Penyakit Infeksi Dengan Kejadian Stunting Di Wilayah Kerja Puskesmas Kerkap Kabupaten Bengkulu Utara Tahun 2019. Avicenna: Jurnal Ilmiah, 14(02), 6-13. https://doi.org/10.36085/avicenna.v14i02.374

Yosephin, B., Darwis, Eliana, Tonny, M., Yuniarti, Anang, W., Afrina, M., \& Mely, G. (2019). Buku Pegangan Petugas KUA: Sebagai Konselor 1000 HPK dalam Mengedukasi Calon Pengantin Menuju Bengkulu bebas Stuting (1st ed.). Deepublish.

Yuliarti, N. (2010). Keajaiban ASI- Makanan Terbaik untuk Kesehatan, kecerdasan, Kelincahan, Si Kecil (Fiva Rosalana (ed.)). Andi Ofset. 